\title{
THE GLOBAL CAPITAL MARKET: BENEFACTOR OR MENACE?
}

\author{
Maurice Obstfeld
}

Working Paper 6559 
NBER WORKING PAPER SERIES

THE GLOBAL CAPITAL MARKET:
BENEFACTOR OR MENACE?

\author{
Maurice Obstfeld
}

Working Paper 6559

http://www.nber.org/papers/w6559

\title{
NATIONAL BUREAU OF ECONOMIC RESEARCH \\ 1050 Massachusetts Avenue \\ Cambridge, MA 02138 \\ May 1998
}

Prepared for the Journal of Economic Perspectives. I thank Alan M. Taylor for ongoing discussions and for permission to draw on our joint work. The paper benefited greatly from careful readings by Brad De Long, Alan Krueger, Dani Rodrik, and Timothy Taylor. Stefan Palmqvist provided expert research assistance. Support from a National Science Foundation grant to the National Bureau of Economic Research is acknowledged with thanks. Any opinions expressed are those of the author and not those of the National Bureau of Economic Research.

(C) 1998 by Maurice Obstfeld. All rights reserved. Short sections of text, not to exceed two paragraphs, may be quoted without explicit permission provided that full credit, including $\odot$ notice, is given to the source. 
The Global Capital Market: Benefactor or Menace?

Maurice Obstfeld

NBER Working Paper No. 6559

May 1998

JEL Nos. F31, F41

\begin{abstract}
This paper reviews the theoretical functions, history, and policy problems raised by the international capital market. The goal is to offer a perspective on both the considerable advantages the market offers and on the genuine hazards it poses, as well as on the avenues through which it constrains national policy choices. A duality of benefits and risks is inescapable in the real world of asymmetric information and imperfect contract enforcement. I argue, however, that in confronting the global capital market there is no reason to depart from conventional economic wisdom. The way to maximize net benefits is to encourage economic integration while attacking concomitant distortions and other unwanted side-effects at, or close to, their sources.
\end{abstract}

\author{
Maurice Obstfeld \\ Department of Economics \\ University of California, Berkeley \\ 549 Evans Hall, \#3880 \\ Berkeley, CA 94720-3880 \\ and NBER \\ obstfeld@econ.berkeley.edu
}


The Asian financial turmoil of 1997 started as a seemingly localized tremor in far-off Thailand, but then swelled into a crisis with repercussions in stock markets on every continent. Both international lending institutions led by the International Monetary Fund, and national governments including those of the United States, Japan, and the European Union, joined in the policy response. The U.S. Federal Reserve, headed for monetary tightening in the fall of 1997, postponed its move for fear of destabilizing world markets further.

These turns of events would have been inconceivable during the 1950s. In that inwardlooking era, most countries' domestic financial systems labored under extensive government restraint and were cut off from international influences by official firewalls. Despite these restrictions, which were a legacy of the Great Depression and World War II, international financial crises occurred from time to time. Between 1945 and 1970, however, their effects tended to be localized, with little discernible impact on Wall Street, let alone Main Street.

Over the past twenty-five years or so this has all changed dramatically. Regional financial crises seem to have become more frequent, and the domestic impact of global financial developments has grown -- to the alarm of many private citizens, elected officials, and even economists. Further change will result from the December 1997 pact on trade in banking, insurance, and other financial services, signed by more than a hundred countries under the aegis of the World Trade Organization. Why has global financial trading grown at such an explosive pace? Does the powerful global market limit our government in the pursuit of legitimate economic and social objectives? Is there any way to prevent destabilizing disturbances that originate in world asset markets, or to mitigate their effects? Does the cross-border mobility of firms threaten our living standards? What benefits could possibly justify exposing ourselves to these risks? 
Definitive answers to these questions remain elusive, but a review of the theoretical functions, history, and genuine policy problems raised by the international capital market offers some perspective on both the considerable advantages it offers and the genuine hazards it poses. This duality of benefits and risks is inescapable in the real world of asymmetric information and imperfect contract enforcement. I shall argue, however, that in confronting the global capital market there is no reason to depart from conventional economic wisdom. The best way to maximize net benefits is to encourage economic integration while attacking concomitant distortions and other unwanted side-effects at, or close to, their sources.

\section{The Integration of Global Capital Markets}

Economic theory leaves no doubt about the potential advantages of global financial trading. International financial markets allow residents of different countries to pool various risks, achieving more effective insurance than purely domestic arrangements would allow. Furthermore, a country suffering a temporary recession or natural disaster can borrow abroad. Developing countries with little capital can borrow to finance investment, thereby promoting economic growth without sharp increases in saving rates. At the global level, the international capital market channels world savings to their most productive uses, irrespective of location. The resulting economic gains are difficult to quantify, as I discuss in a moment, and may work through subtle mechanisms. For example, producers who can diversify risks in financial markets may undertake more high-yield but risky investments, increasing average rates of economic growth. In that case the welfare gains can be enormous (Obstfeld, 1994).

The other main potential positive role of international capital markets is to discipline 
policymakers who might be tempted to exploit a captive domestic capital market. Unsound policies--for example, excessive government borrowing or inadequate bank regulation--would spark speculative capital outflows and higher domestic interest rates. In theory, a government's fear of these effects should make rash behavior less attractive.

It is difficult to quantify the gains countries have realized from international capital mobility, since a rigorous attempt would require a fully-articulated model in which the counterfactual of no capital movements could be simulated. Historical evidence is suggestive of substantial benefits, however, notably for smaller countries, which are likely to gain the most from trade. Norway borrowed as much as 14 percent of gross domestic product in the 1970s to develop its North Sea oil reserves. Portugal borrowed as much as 17 percent in the early 1980s to modernize its economy; the country was chosen in May as a founder member of the European Union's economic and monetary union (EMU). Preliminary forecasts by the Organization for Economic Cooperation and Development put Poland's 1998 and 1999 foreign borrowing at around 6 percent of GDP. Strong foreign investment inflows have fueled falling unemployment and a high rate of capital accumulation. However, the non-negligible risk that the Polish economy will overheat and succumb to a financial crisis, despite restrictive domestic macro policies, illustrates a serious pitfall of access to the global capital market to which I return below. Borrowers may overextend themselves, sparking an investor panic in which foreign debts cannot be repaid on time.

Given the benefits of a global capital market, why was the market still so fragmented and limited in scope a full generation after the end of War II? It had not always been so. Until World War I, a vibrant, free-wheeling capital market linked financial centers in Europe, the western 
hemisphere, Oceania, Africa, and the Far East. A nineteenth-century reader of the Economist magazine could track investments in American railroads, South African gold mines, Egyptian government debt, Peruvian guano, and much more. The laying of the trans-Atlantic cable in 1866 reduced the settlement time for intercontinental transactions from roughly ten days (the duration of a steamship voyage between Liverpool and New York) to only hours (Officer 1996, p. 166). This enormous communications advance of the era was perhaps more significant than anything that has been achieved since.

The international financial market broke up during World War I, made a brief comeback between 1925 and 1931, and then withered in the Great Depression. At that time, governments everywhere limited the scope of domestic financial markets as well, imposing tighter regulation and prohibiting myriad activities outright. World War II cemented the demise of the global capital market. As late as 1950, the world's major economies remained linked only by the most rudimentary, and typically bilateral, trade and financial arrangements. However, private capital movements began to return in the 1960s, grew rapidly in the 1970s, and then grew even faster in the 1980s (though global capital largely bypassed the developing countries mired in that decade's debt crisis). The worldwide trend of financial opening in the 1990s has restored a degree of international capital mobility not seen since this century's beginning.

These developments can be documented through data on international financial flows and asset prices. ${ }^{1}$ Table 1 shows data on one such measure, the current account balance from 1870 through the present, for 12 countries, reported as the absolute value of the current account divided by gross domestic product. The current account balance, of course, is the difference between national saving and domestic investment: if positive, it measures the portion of a 
country's saving invested abroad; if negative, the portion of domestic investment financed by foreigners' savings. The final column of the table presents the average over the 12 countries for different time periods. While international investment flows commonly topped 3 percent of GDP before 1914, they slumped to half that level in the 1930s and only after 1970 began to move decisively upward. The relatively high imbalances during wars represent government rather than private borrowing. Even today, the average level of current account balances has not quite attained the magnitude that was common before World War I.

Figure 1 offers another indicator of capital mobility, the standard deviations of the difference between one-year interest rates on sterling-denominated assets sold in New York and those sold in London. (See Obstfeld and Taylor, 1998, for data on levels of mean annual interest differentials.) The interest differential, as well as is variability, should equal zero if capital mobility between the two centers is perfect, but these measures can deviate from zero in the presence of transaction costs, political risks, and other barriers to the free flow of money. In practice, differences in the American and British financial instruments chosen for comparison also can lead to interest differences. By focusing on return standard deviations, I downplay such discrepancies, which are not necessarily evidence of financial-market segmentation.

Under the pre-1914 gold standard, New York-London differentials show relatively small fluctuations (and they do so around a declining trend average differential). Differentials start to open up during World War I, become quite large by the early 1920s, and decline briefly in the late 1920s before widening sharply in the early 1930s through the early 1950s. Some arbitrage gaps remain in the mid-1950s, but the variability of return differentials is generally quite small after the early 1950s, and through the late 1960s. This degree of financial market cohesion in the 1950s 
and 1960s reflects New York's and London's positions as world financial centers, and is not typical of most other industrial country pairs (Marston 1995). Interest gaps open up sharply again in the late 1960s, but have become progressively steadier and smaller since the early 1970s, once again reaching levels close to those of the later classical gold standard years, 1890-1914.

What explains the long stretch of high capital mobility that prevailed before 1914, the subsequent breakdown in the interwar period, and the very slow postwar reconstruction of the world financial system? The answer is tied up with one of the central and visible areas in which openness to the world capital market constrains government power: the choice of an exchange rate regime.

\section{Capital Mobility, the Exchange Rate and Monetary Policy}

It is a trite but true assertion of international monetary economics that the exchange rate is an open economy's most important price. The United States has become ever more open to trade since the end of World War II, as Robert Feenstra documents in his article in this symposium. Exchange rate movements therefore have increasingly become a cause for public and official concern.

\section{A Fundamental Tradeoff}

In most of the world's economies, the exchange rate is a key instrument, target, or indicator for monetary policy. An open capital market, however, deprives a country's government of the ability simultaneously to target its exchange rate and to use monetary policy in pursuit of other economic objectives. As an example, consider Austria, which for more than two decades 
has pegged the exchange rate between its currency, the schilling, and the German mark. Since market participants understand that the exchange rate will not change by more than a few basis points, nominal interest rates in Austria must closely match those in Germany. The rates are kept in line by arbitrageurs who would massively borrow in the currency with the lower interest rate and lend in the currency with the higher interest rate, confident that their gains will not be erased by a movement of the exchange rate. But equality of interest rates also means that Austria cannot conduct a monetary policy independent of Germany's; both Austria's exchange rate and interest rate will be determined exogenously. Since it is Austria (and not Germany) that is pegging the exchange rate, the Austrian central bank has only one monetary role, to offset any incipient change in the schilling's exchange value against the mark.

Austria can regain an independent monetary policy in two ways. If it could prohibit any cross-border financial transactions, Austria would cut off the arbitrageurs and decouple its interest rate from Germany's, but could still maintain the fixed exchange rate. In that case, Austria might unilaterally lower its interest rates, for example, but investors no longer would have the right to move funds from Vienna to Frankfurt in response to the resulting return differential. Pressures in the foreign exchange market would be limited to mark demands from Austrian importers and from exporters to Austria wishing to convert their schilling earnings into marks. Any exchange-rate effect of these trade-driven demands for marks, which are orders of magnitude below the potential demands associated with international financial flows, could normally be offset by sales of Austrian official mark reserves as necessary.

Alternatively, Austria could maintain freedom of private capital movement but allow the schilling/mark rate to float. In that case, Austria would be free to lower its interest rates, but the 
schilling would depreciate against the mark as a result. Both developments would tend to spur aggregate demand for Austrian output.

The limitations that open capital markets place on exchange rates and monetary policy often are summed up by the idea of the "inconsistent trinity" or, as Alan Taylor and I have labeled it, the "open-economy trilemma" (Obstfeld and Taylor, 1998): that is, a country cannot simultaneously maintain fixed exchange rates and an open capital market while pursuing a monetary policy oriented toward domestic goals. Governments may choose only two of the above. If monetary policy is geared toward domestic considerations, either capital mobility or the exchange rate target must go. If fixed exchange rates and integration into the global capital market are the primary desiderata, monetary policy must be subjugated to those ends.

The choice between fixed and floating exchange rates should not be viewed as dichotomous. In reality, the degree of exchange-rate flexibility lies on a continuum, with exchange-rate target zones, crawling pegs, crawling zones, and managed floats of various other kinds residing between the extremes of floating and irrevocably fixed. Indeed, the notion of a "free" float is an abstraction with little empirical content, as few governments are willing to set monetary policy without some consideration of its exchange-rate effects. However, the greater the attention given to the exchange rate, the more constrained monetary policy is in pursuing other objectives. $^{2}$

Understanding the Evolution of International Capital Mobility

The broad trends and cycles in the world capital market over the last century reflect changing responses to the fundamental policy trilemma. Before 1914, each of the world's major 
economies pegged its currency's price in terms of gold, and thus, implicitly, maintained a fixed rate of exchange against the currency of every other major country. Financial orthodoxy saw no alternative mode of sound finance. Latin American interludes of floating exchange rates were viewed from the main financial centers with "fascinated disgust," to use the words of Bacha and Díaz-Alejandro (1982).

The gold standard system met the trilemma by opting for fixed exchange rates and capital mobility, sometimes at the expense of domestic macroeconomic health. Between 1891 and 1897 , for example, the U.S. Treasury allowed the domestic money stock to contract sharply in the face of persistent speculation that the dollar would leave gold. This policy led to banking panics and a harsh deflation. A populist movement led by William Jennings Bryan and others agitated forcefully against gold, but lost. The balance of political power began to change only with World War I, which brought a sea-change in the social contract governing the industrial democracies (Temin, 1989). Organized labor emerged as a political power, a counterweight to the interests of capital. Although Britain's return to gold in 1925 led the way to a restored international gold standard and a limited resurgence of international finance, the gold standard helped propagate a worldwide depression after the 1929 New York stock market crash. Many countries abandoned the gold standard in the early 1930s and depreciated their currencies; many also resorted to trade and capital controls to manage independently their exchange rates and domestic policies. However, countries in the "gold bloc," which stubbornly clung to gold through the mid-1930s, showed the steepest output and price-level declines. Eventually in the 1930s, virtually all countries jettisoned rigid exchange-rate targets, open capital markets, or both in favor of domestic macroeconomic goals. ${ }^{3}$ 
In this way, the Great Depression discredited gold standard orthodoxy and made financial markets and financial practitioners unpopular. Their supposed speculative excesses and attachment to gold became identified in the public mind as causes of the economic calamity. Financial products and markets were banned or more closely regulated. In the United States and elsewhere, central banks were brought under heavier Treasury influence. Worldwide, a new consensus developed in which preserving the value of the currency ran a distant second to maintaining high employment.

These changed attitudes underlay the new postwar economic order negotiated at Bretton Woods, New Hampshire, in July 1944. Forty-four allied countries set up a system based on fixed, but adjustable, exchange parities, in the belief that floating exchange rates would exhibit instability that would damage international trade. At the center of the system was the International Monetary Fund (IMF). The IMF's prime function was as a source of hard-currency loans to governments that might otherwise have to put their economies into recession to maintain a fixed exchange rate. Countries suffering protracted balance-of-payments problems had the option of realigning their currencies, subject to IMF approval.

The IMF's founders viewed its lending capability as primarily a substitute for private capital inflows, not a complement to them. Interwar experience had given private capital flows a reputation as unreliable at best and, at worst, a dangerous source of disturbances. Encompassing controls over private capital movement, perfected in wartime, were expected to continue. The IMF's Articles of Agreement explicitly empowered countries to impose new capital controls, prohibited members from using IMF resources "to meet a large or sustained outflow of capital," and even gave the Fund the right to request that capital controls be imposed in such cases 
(Horsefield, 1969, pp. 193-4). As Treasury Secretary Henry Morgenthau proclaimed at Bretton Woods, the new IMF and its sister institution, the World Bank, would "drive ... the usurious money lenders from the temple of international finance" (Gardner, 1980, p. xix). The maintenance and even extension of capital account controls had the additional advantage of placating a U.S. Congress worried that taxpayers' money would disappear down foreign "rat holes," as Republican Senator Robert A. Taft of Ohio put it (as quoted in Gardner, 1980, p. 130).

Article VIII of the IMF agreement did demand that countries' currencies eventually be made convertible -- in effect, freely saleable to the issuing central bank, at the official exchange parity, for dollars or gold. But this privilege was to be extended only to nonresidents (not a country's own citizens), and mainly if the country's currency had been earned through sales of goods and services. (Convertibility for currency acquired through financial trades was not viewed as mandatory, or even as desirable.) But even this limited convertibility took years to achieve, and in the interim, countries resorted to bilateral trade deals that required balanced or nearly balanced trade between every pair of trading partners. If France had an export surplus with Britain, and Britain a surplus with Italy, Britain could not use its excess lire earnings to obtain dollars with which to pay France. Italy had very few dollars and guarded them jealously for critical imports from the Americas. Instead, each country would try to divert import demand toward countries with high demand for its goods, and to direct its exports toward countries whose goods were favored domestically.

Convertibility gridlock in Europe and its dependencies was eventually ended through a regional multilateral clearing scheme, the European Payments Union (EPU). The clearing scheme was set up in 1950 and some countries reached de facto convertibility by mid-decade. But it was 
not until December 27, 1958, that Europe officially embraced convertibility and ended the EPU.

The return to convertibility was important in promoting growth in multilateral trade.

However, most European countries still chose to retain extensive capital controls, with Germany being the main exception. As trade increased, however, so did opportunities for disguised capital movements. These might take the form, for example, of misinvoicing, and then accelerated or delayed merchandise payments. Buoyant economic growth encouraged some countries in further financial liberalization, although the United States, worried about its gold losses, raised progressively higher barriers to capital outflow over the 1960s.

Eventually, the very success of the Bretton Woods system in spurring international trade and the related capital movements brought about its own collapse by resurrecting the "inconsistent trinity." For the United States, maintaining fixed exchange rates seemed to require high interest rates and slower growth; for Germany, fixed exchange rates seemed to require giving up domestic control over inflation. Even the relatively limited capital mobility that existed by the early 1970s allowed furious speculative attacks on the major currencies. After vain attempts to restore fixed dollar exchange rates, the industrial countries moved to floating rates early in 1973. Although viewed at the time as a temporary emergency measure, the floating-dollar-rate regime is still with us a quarter-century later.

\section{Capital Mobility and Exchange-Rate Flexibility}

Floating exchange rates have allowed the explosion in international financial markets experienced over that same quarter-century. Freed from one element of the trinity -- fixed exchange rates -- countries have been able to open their capital markets while still retaining the 
flexibility to deploy monetary policy in pursuit of national objectives. ${ }^{4}$

Numerous countries have tried to fix their exchange rates for various reasons, but few have been willing or able to do so for long. Sooner or later, exchange-rate stability tends to come into conflict with other policy objectives to which votes attach greater priority. Once the capital markets catch on to the government's predicament, a crisis can add enough economic pain to make the authorities give in.

In an earlier article in this Journal, Kenneth Rogoff and I observed that only a very few major countries had observed the discipline of fixed exchange rates for at least five years, and that most of those were rather special cases (Obstfeld and Rogoff, 1995). The case that most puzzled us, Thailand, has dropped off the list -- with a resounding crash. Even Hong Kong, which operates as a currency board supposedly subordinated to maintaining the Hong Kong-U.S. dollar peg, has suffered continuing speculative pressure in 1997-98, withstanding persistently high interest rates with Beijing's support. ${ }^{5}$ Another currency-board country, Argentina, has now held to its 1:1 dollar exchange rate since April 1991, and so joins the exclusive five-year club. To accomplish that feat, the country has relied on IMF credit and has suffered unemployment higher than many countries could tolerate (nearly 15 percent in 1997). The European Union members that have recently maintained mutually fixed rates have been aided by market confidence in their own planned solution to the policy trilemma, a full currency merger due to be consummated in January 1999. But they too have paid a price in terms of joblessness. The trend toward greater financial openness in developing countries has been accompanied -- inevitably, I would argue -- by a declining reliance on pegged exchange rates in favor of exchange rate flexibility. ${ }^{6}$ 


\section{Fiscal Autonomy and Income Distribution}

An open capital market immediately confronts national authorities with a decision over controlling either interest rates or exchange rates. Over the medium term, integration into the global capital market also makes it more difficult to tax internationally footloose capital relative to less mobile factors of production, notably labor. This loss of fiscal options could be costly, but just how costly remains unclear.

International Tax Competition

When capital can move freely across national borders, it will flee counties where it is taxed heavily to production locations where taxes are lower. Indeed, accounting practices allow the base for capital taxes to migrate even when capital itself does not. Simply by altering the accounting value attached to intermediate goods being shipped within the company, a multinational enterprise can arrange to book relatively large shares of its worldwide profits in countries with low rates of corporate tax (Tanzi, 1996). Such strategic bookkeeping adjustments can take place even more quickly than capital itself can be transferred between countries.

If capital (or the capital tax base) can migrate very quickly, individual countries lose some of their autonomy with respect to capital tax rates. ${ }^{7}$ Absent special features making for an attractive investment locale -- like a high level of public goods or skilled but inexpensive labor -- a country must lower its capital tax rates to match those set by foreign authorities. Otherwise it suffers a diminished tax base and, possibly, a lower domestic living standard. Moreover, individual countries have incentives to tailor their tax policies so as to lure business from abroad. There is potentially a "race to the bottom" as countries competitively offer tax breaks in a collectively self- 
defeating scramble for national advantage.

International "tax poaching" is indeed a well-established practice. EU countries are attempting to ban poaching internally, putting heavy pressure on Ireland, for example, to end the preferential 10 percent corporate tax rate it has offered to lure investment from abroad. OECD countries show a clear trend of declining corporate tax rates over the last decade (Tanzi, 1996, p. 14), though it is unclear how important tax competition (as opposed to ideological change, for example) has been in this development. As for the noncorporate sector, it has become increasingly hard these days to tax the income that residents earn on assets held overseas. Scandinavian countries have already moved toward a "dual" income tax, with lower taxation of income from capital than of labor earnings.

How Great is the Threat to National Autonomy?

Many observers fear that the constraint of financial openness poses a dilemma for fiscal policy: either the burden of providing necessary social services must be shifted toward labor, or those services must be scaled back. Rodrik (1997), for example, argues that greater economic openness is associated with greater uncertainty over consumption, especially for workers, who at best can insure very little of their income in markets. Government expenditure and social support programs, Rodrik contends, have evolved to provide substitute insurance against those risks and others. He presents regression evidence suggesting that greater openness leads to lower taxes on capital and higher taxes on labor, and that capital-account restrictions have allowed heavier capital taxation. Rodrik foresees that the downward leveling of capital taxes will either raise the tax burden on labor to politically unacceptable levels, or else compromise the social and worker 
protection programs that, in his view, have allowed countries gradually to lower trade barriers over the postwar period. A popular backlash against free trade might result.

Such alarming scenarios raise several natural questions. Does international tax competition offer any benefits that might be set off against the costs? Is there evidence that international tax competition has already harmed, or is near to harming, crucial social programs? How far can we expect the process of capital-tax leveling to go? Finally, if policy interventions are needed, what forms should they take?

A basic point to keep in mind is that is that there is a strong case to be made on pure efficiency grounds that taxes on capital should be low, to encourage long-term investment and higher living standards. (Lucas 1990 reviews this result within a dynamic Ramsey tax model.) Even in a closed economy, the burden of high capital taxes will be shifted toward labor as savings shrink. From this perspective, pressure for lower capital taxes may be a good thing.

Looking at the effects of international tax competition so far, it is hard to argue that we see anything close to equivalent overall capital tax rates across countries, or equivalent levels of social spending. For example, Germany, which has long had an open capital account, devoted 21.2 percent of its GDP to government social security payments and transfers in 1995, compared to 13.9 percent in the United States. The ratio for France was 25.7 percent in the same year. Sørensen (1993) observes that proceeds from the corporate income tax did not fall over the 1980s in industrial countries, either as a share of GDP or of total revenues, despite generally lower statutory tax rates. The reason was a broadening of the corporate tax base.

It is difficult to say how far global tax competition might go in the long run. Eichengreen (1990) finds that the variability of state tax rates in the United States (through the early 1980s) 
was 40 percent below that among European Union states, but far from zero. It is hard to measure the differential levels of public goods that states might provide (in the form of infrastructure and so on) or other special locational incentives they might offer. However, the U.S. states have a much higher degree of economic integration than do the nations of Europe. Thus, a cautious conclusion would be that the global capital market will push countries at most part way toward the predicament Rodrik (1997) fears. ${ }^{8}$

To the extent the problem does arise, however, how can countries best deal with it? Overt restrictions on capital outflows seem an inefficient way to address the issue; they would be difficult and costly to enforce, they imply resource misallocations, and there is no support in the business community for preventing capital outflows. For countries that face revenue shortfalls in financing necessary social protection programs, it would be far better to shift from capital taxes to a consumption tax rather than to a tax on labor incomes. (There is already a trend in industrialized countries toward heavier taxation of consumption; see King, 1996.) Furthermore, many industrial countries' social protection programs could offer adequate insurance at lower cost. In Europe, for example, often open-ended and largely unconditional social benefits, coupled with the employment disincentives that firms face, lead to programs that expend large sums on long-term income support rather than true insurance (Siebert, 1997).

If tax competition nonetheless emerged as a threat to social cohesion or to free trade, formal international tax coordination might begin to appear attractive, despite the daunting difficulties in reaching a deal geographically comprehensive enough to be effective. 


\section{Capital Mobility and Income Distribution}

Debate on the changing distribution of United States wages and rising European unemployment has focused on imports from low-wage countries (as discussed in Feenstra's contribution to this symposium). In principle, however, capital movements and commodity imports can have identical effects on wages, as shown in a classic analysis by Mundell (1957), which raises the possibility that the global capital market, in addition to hindering governments' provision of social insurance, might increase inequality and raise the need for those same insurance services.

The Mundell (1957) story works as follows. According to the usual Heckscher-Ohlin reasoning, increased trade between high-wage United States and low-wage Mexico has a depressing effect on the wages of low-skilled American workers, who must find new jobs in sectors that previously had employed relatively few of them. Consider the effects, however, when a General Motors plant moves south of the border to avail itself of cheaper Mexican labor. Since there is now less capital in the United States relative to the supply of workers, wages will need to fall to restore full employment in the United States, while wages will rise in Mexico. Bottom line: low-wage Americans are threatened both by importing the goods low-wage foreign workers produce, and also by equipping foreign workers with exported U.S. capital.

A vital corollary is that import restrictions cannot prevent factor-price convergence when capital markets are open. Since capital seeks out its most remunerative global use, trade restrictions provoke large-scale capital movements that equalize factor prices directly, and simultaneously eliminate the gains from commodity trade.

While the "great sucking sound" of firms relocating in low-wage countries has loomed 
prominently in the news media, aggregate investment patterns make it look implausible that the mechanism has so far had much impact on U.S. or European labor markets. The United States has been running substantial current account deficits since the mid-1970s; thus, the net effect of capital-market integration has been to allow the U.S. to invest more than it could have out of its own savings alone. To show that low-skilled American workers have been injured through the capital-flow channel, one would have to argue not that U.S. workers have been hurt by U.S. capital moving abroad, but rather that they have been hurt by foreign capital arriving here, perhaps because such workers' services are highly substitutable for those of capital. In contrast, the European Union has on average run current account surpluses since the mid-1970s, but these have typically been 0.4 percent of GDP or less -- much too small to explain the substantial rise in European unemployment over that time.

\section{Market Failures and the Policy Response}

I have argued that the international capital market has the potential to yield great benefits, but that it also constrains national choices over monetary and fiscal policies, and may facilitate excessive borrowing. To what extent is the positive potential of the international capital market outweighed by a potentially disruptive role? Are there policy reforms or institutional changes that might improve the balance of benefits and costs? Here, I discuss three facets of the debate: the very low degree of international diversification of equity portfolios; the problem of international capital-market crises, much in the news recently; and the role of the IMF as an international emergency lender. 


\section{The International Diversification Puzzle}

The opportunities for global risk sharing that the international capital market offers should lead investors to diversify their portfolios over investments in many countries. In practice, however, little of the sort seems to have happened. The majority of investors seem to remain parochial in outlook, choosing to retain most of their wealth at home.

In an article that drew attention to the extent of the international diversification puzzle, French and Poterba (1991) pointed out that at the end of the 1980s, U.S. investors held 94 percent of their equity wealth in U.S. equities and Japanese investors held 98 percent of theirs in Japanese equities, while French, German, and even Canadian investors held only around 1 percent of their equity wealth in U.S. or Japanese equities. Such wildly unbalanced allocations are hard to reconcile with any intuitive notion of a well-diversified portfolio. As a first pass, one might expect people to diversify by "holding the market," that is, by demanding a country's stocks in rough proportion to its share in global market capitalization. International diversification has occurred in the 1990s, but even the much publicized growth of U.S.-based global equity mutual funds has not nearly erased the basic puzzle raised by the French-Poterba data. ${ }^{9}$

What explain the apparent failure of people to take full advantage of such an obvious opportunity for mutual gain? Nobody knows. Part of the puzzle could reflect the fact that increasingly the profit streams associated with "domestic" companies in fact reflect production operations abroad. And foreign direct investment is indeed substantial. People can and do diversify abroad by holding foreign non-equity assets. In addition, estimates of supposedly optimal portfolios are quite imprecise, and can encompass wealth allocations heavily skewed toward home-based industries. Nonetheless, the weight of the evidence suggests significant unexploited 
diversification opportunities (Lewis, 1997).

Unfamiliarity with foreign products, firms, business practices, accounting standards, political trends, and regulatory environments surely play some role. An American investor, for example, may feel disadvantaged in assessing the future prospects of a French firm, and may find the cost of becoming informed excessive. Many industrial-country stock exchanges now have substantial listings of foreign firms, but outside of London, that development hasn't led to substantial domestic trade in their shares. For example, the Amsterdam market's listings in 1996 were divided about equally between domestic and foreign companies, yet more than 99 percent of its turnover that year was in domestic shares (Folkerts-Landau et al., 1997, p. 198).

The puzzle therefore remains. At present the global capital market enforces rather tight arbitrage among the returns on standardized securities that are subject to risks along only a few well-understood (and easily hedged) dimensions. But such trades go only a small way toward realizing the potential gains from risk sharing. International trade in less homogeneous and riskier assets is growing all the time, but remains less developed. ${ }^{10}$

Crises in the Capital Markets

The year 1982 marked the start of a global developing-country debt crisis. Private lending to the affected developing countries, many of them in Latin America, slowed to a reluctant trickle, while sovereign debtors and their creditors teetered on the edge of generalized default. But in the 1990s, the debt crisis gave way to renewed capital inflows, as a combined result of workouts of the old debt problems, widespread economic reforms, and low American interest rates (see Calvo, Leiderman, and Reinhart, 1996). 
In the 1990s, foreign exchange crises have disrupted exchange markets in Europe, Latin America, and east Asia. Outside of Europe, the crises have spilled into stock markets, raised the specter of state default, and sometimes led to deep recessions. Most of the east Asian countries avoided debt problems in the 1980s, but several have been hit hard in the 1990s. The crises have sharpened debate over two opposing views. One claim is that otherwise successful economies have been victims of greedy market operators, usually foreign ones. This view is especially popular with government ministers in the afflicted countries. In the 1960s, anonymous "gnomes of Zurich" were blamed for Britain's chronic balance of payments problems; in the 1990s, ministers name gnomes (like George Soros). The opposing view is that such crises are largely home-grown, and that the global capital market is simply performing a needed role in disciplining imprudent government policies.

Recent thinking on crises would argue that neither view is entirely correct. There may be extensive "grey areas" in which unwise policies make countries vulnerable to crises, but in which a crisis is not inevitable and might in fact not occur without the impetus of international capital outflows, typically carried out by domestic as well as foreign investors (see, for example, Detragiache, 1996, and Obstfeld, 1996). For example, a country with extensive short-term dollardenominated government debts and few dollar reserves -- Mexico's`position in December 1994 -might find itself in a crisis if previous lenders all suddenly demand repayment of their dollars, and if no new lenders of dollars can be found. Thus, crises may contain a self-fulfilling element, just as bank runs do, which can generate multiple equilibria in international asset markets, and render the timing of crises somewhat indeterminate. What we see in these cases is a sharp break from an essentially tranquil equilibrium to a crisis state, rather than a gradual deterioration in domestic 
interest rates and other market-based indicators. This view helps explain why capital markets can appear to impose too little discipline before the crisis arrives, and too harsh a discipline afterwards.

The attempt to assure fixed exchange rates (or a preannounced ceiling on exchange depreciation) can lead to the very vulnerabilities that raise the possibility of an international credit crisis. When domestic banks and corporate borrowers are (over)confident in an exchange rate, they may borrow dollars or yen without adequately hedging against the risk that the domestic currency will be devalued, sharply raising the ratio of their domestic-currency liabilities to their assets. They may believe that even if a crisis occurs, the government's promise to peg the exchange rate represents an implicit promise that they will be bailed out in one way or another. Borrowers may face little risk of personal loss even if a bailout does not materialize.

This problem has been especially severe in developing countries, where prudential regulation is looser, financial institutions are weaker, and even the government's credit may be questionable. When market sentiment turns against the exchange rate peg, the government is effectively forced to assume the short foreign-currency positions in some way -- or else to allow a cascade of domestic bankruptcies. Since the government at the same time has used its foreign exchange reserves (in a vain attempt to peg the exchange rate) and cannot borrow more in world credit markets, national default becomes imminent. ${ }^{11}$ Díaz-Alejandro (1985), describing Chile's experience in the early 1980s, gave a classic account of this process.

The exchange crises of the 1990s have underlined the problem anew. In Mexico, domestic financial institutions in the early 1990s borrowed (or took short positions) at low interest rates in U.S. dollars so as to profit from higher Mexican interest rates. In many cases they did this through 
special instruments designed to circumvent Mexican prudential regulations (Garber and Lall, 1998). When the peso crisis struck at the end of 1994, Mexico's government found itself facing both a private-sector financial crisis along with the problems arising from the government's own dollar-linked foreign borrowing. It saw no choice but to provide foreign reserves and liquidity to banks, thus fueling the peso's further depreciation.

Similar patterns can be seen in east Asia. As the IMF observes concerning Thailand (Folkerts-Landau et al., 1997, p. 46):

While banks are believed to have hedged most of their net foreign liabilities, the opposite is believed to be true for the corporate sector. The combination of a stable exchange rate and a wide differential between foreign and (much higher) domestic interest rates provided a strong incentive for firms to take on foreign currency liabilities .... Hence, in addition to their own foreign exchange exposure, banks may have a large indirect exposure in the form of credit risk to firms that have borrowed in foreign currencies.

The Thai authorities intervened extensively in exchange markets after the crisis started in May 1997, by committing to contracts under which the government would assure future trades of dollars for baht (the Thai currency) near current spot prices. This policy allowed many of those short on dollars to cover their liabilities relatively cheaply. As a result, the Thai government was stuck with billions in foreign exchange liabilities after the baht was floated in July, and these additional debts fueled the crisis further. ${ }^{12}$

When currency crises struck Europe in 1992, its governments' credit did not come 
seriously into question. Europe's exchange-rate crises therefore did not balloon into more damaging default crises as in Mexico and Asia, capital market access was not interrupted, and there was no need to seek emergency support from foreign governments or the IMF.

The recent east Asian episodes again underline the need for more effective monitoring and regulation of the asset and liability structures of financial institutions. The recent episodes also underline the often weak political will to carry out such supervision, the lack of local expertise, and the difficulty in discerning the true risk characteristics of institutions' assets and liabilities. ${ }^{13}$ Particularly when borrowing is short-term, capital inflows may quickly reverse course and turn into outflows, squeezing liquidity and ultimately draining official reserves. This is what happened, on a global scale, in 1982. Such events are familiar from the record of bank failure in a purely domestic context, but the emerging-market setting combines an additional risk -- currency risk -with the lack of a well-defined lender of last resort, transparent accounting practices and legal systems, and (often) adequate prudential supervision. (Even in many industrial countries financial deregulation in the 1980s led to massive banking problems in the early 1990s.)

If more effective supervision proves impossible for a country, then there is a second-best case for limiting foreign capital inflows through taxes on capital imports, foreign deposit requirements, or similar measures. The possible moral hazard problem raised by fixed exchange rates suggests an argument for exchange-rate flexibility (Mishkin, 1996). By purposely leaving some scope for unexpected exchange rate movements and avoiding implicit exchange-rate guarantees, the authorities can induce domestic borrowers to internalize at least some of the costs of failing to hedge appropriately. Other steps that would reduce the scope for crises would be more foreign equity ownership in developing countries, and particularly ownership of developing- 
country financial institutions, coupled with greater representation in financial sectors of foreignbased intermediaries. These developments would have the side-benefit of reducing the perceived chance of government bailouts.

While private financial mismanagement and inadequate supervision bear much of the blame for recent developing-country capital-market crises, one should not conclude that international capital movements are necessarily stabilizing in the absence of underlying vulnerabilities. Calvo and Mendoza (1997) show that when international investors can allocate their wealth over many risky foreign investments and face a fixed cost of information about each country, it may pay for individuals to diversify widely without bothering to become informed. In this situation, capital flows can be volatile and subject to herding effects. Any mechanism for providing low-cost information to markets -- for example, credible data on official foreign reserves, the maturity of foreign borrowing, and the quality of domestic investments -- is a public good in this kind of model. In line with that conclusion, the IMF has been pressing countries to accelerate and broaden their disclosure of key economic data (although it is hard to verify the data that are disclosed, and harder still to believe that a government in difficulty would release damning figures). I conclude by taking up the Fund's other major initiatives on capital markets, which have placed the organization at center stage as an advocate of open financial markets and as an international lender of last resort.

The IMF as an Emergency Lender

The U.S. government drew the IMF into the 1994 Mexican rescue. The organization then took the lead role in helping Argentina stave off the subsequent "tequila" crisis -- an Argentinean 
headache blamed by many on Mexico's election-year binge. By 1997, the Fund was orchestrating international rescue efforts for Thailand, Indonesia, and Korea, putting up tens of billions of dollars itself and imposing stiff conditions on the borrowers.

In reality, the IMF has been seeking a new permanent role ever since the demise of the Bretton Woods system it was designed to oversee. It has eagerly embraced the role of international lender of last resort, and has requested extra resources for that purpose. (At the IMF's 1997 annual meeting in Hong Kong, shareholder nations agreed to increase its \$200 billion capital by 45 percent.) The IMF is also seeking a proposed amendment to its Articles of Agreement, which would codify the Fund's role in promoting open capital markets, as well as member countries' obligation to work, gradually if need be, toward that same goal (Fischer, 1997). Article VIII of the original IMF agreement pushed countries to establish currency convertibility as necessary to facilitate trade, and the Fund stood ready with resources should this obligation lead to pressures on their fixed exchange rates. The proposed article amendments in effect would oblige the Fund to stand ready with backstop finance should private capital flows prove troublesome. After all, the IMF can hardly let countries that have followed its advice twist slowly in the wind if things go awry.

The Fund clearly is right, it seems to me, to advocate an orderly process of progressive integration into world capital markets. Convertibility for current-account transactions seemed risky as well in the 1940s, but it proved an unprecedented engine for global growth. International finance likewise can be an engine of growth, as it has been in the past. For this to occur, however, adequate prudential safeguards must be in place first; capital markets must be competitive and free of government-sponsored favoritism; and investors and capital recipients alike must be motivated 
to avoid excessive risks and make use of new avenues for diversification. ${ }^{14}$ These are tall, but not hopeless, orders. The Fund's official espousal of financial openness represents a break with the attitudes of its founders, but one that seems entirely realistic after a half-century of financialmarket recovery.

While the IMF's expanded lending role certainly offers potential benefits, it once again raises the moral hazard problem that market agents may take on riskier behavior, in the expectation that if they fail, an IMF-arranged bailout is at least possible, if not probable. To some degree, the IMF can reduce this risk by monitoring the behavior of potential claimants on its resources. But it is much harder for the Fund to monitor and regulate sovereign countries -- who are, remember, the shareholders in the IMF -- than it is for a nation's bank regulators to monitor its home financial system (Goldstein and Calvo, 1996).

Furthermore, the Fund's credibility in foreswearing such bailouts is suspect from the start. Strategic considerations and contagious threats to healthier economies might promote intervention. Moreover, is it plausible that the Fund would deny resources in a pinch, possibly condemning millions of innocent people to avoidable suffering? In discussing the 1995 Mexican support package, the IMF's First Deputy Managing Director, Stanley Fischer (1996, p. 323), observed, "It would no doubt have been salutary for the Mexican policymakers and for the investors to pay the right price for their sins. But the problem is that ordinary Mexicans would have borne much larger costs. That's justification enough for the international action." It remains to be seen how an institution with an essentially humanitarian mission can square this circle. The Fund has faced this dilemma since its inception, but the game is a new one, with higher stakes than ever before. 


\section{Summary}

Postwar experience has been characterized by a growing acceptance of economic openness. Compared to the world of the late nineteenth century gold standard, however, we increasingly reside in broadly democratic societies in which voters hold their governments accountable for providing economic stability and social safety nets. These imperatives sometimes seem to clash with the reality of openness. Despite periodic crises, global financial integration holds significant benefits and probably is, in any case, impossible to stop -- short of a second great depression or third world war. The challenge for national and international policymakers is to maintain an economic and political milieu in which the trend of increasing economic integration can continue. 


\section{References}

Alesina, Alberto, Vittorio Grilli, and Gian Maria Milesi-Ferretti, "The Political Economy of Capital Controls." In Leiderman, Leonardo, and Assaf Razin, eds., Capital Mobility: The Impact on Consumption, Investment and Growth. Cambridge: Cambridge University Press, 1994.

Bacha, Edmar Lisboa, and Carlos F. Díaz-Alejandro, International Financial Intermediation: A Long and Tropical View, Princeton Essays in International Finance 147, May 1982.

Calvo, Guillermo A., Leonardo Leiderman, and Carmen M. Reinhart, "Inflows of Capital to Developing Countries in the 1990s," Journal of Economic Perspectives, Spring 1996, 10, 123 39.

Calvo, Guillermo A., and Enrique G. Mendoza, "Rational Herd Behavior and the Globalization of Securities Markets," Discussion Paper 120, Institute for Empirical Macroeconomics, Federal Reserve Bank of Minneapolis, August 1997.

Collins, Susan M., "On Becoming More Flexible: Exchange Rate Regimes in Latin America and the Caribbean," Journal of Development Economics, 1996, 51, 117-38.

Detragiache, Enrica, "Rational Liquidity Crises in the Sovereign Debt Market: In Search of a Theory," IMF Staff Papers, September 1996, 43, 545-70.

Díaz-Alejandro, Carlos F., "Goodbye Financial Repression, Hello Financial Crash," Journal of Development Economics, September/October 1985, 19, 1-24.

Dooley, Michael P., "A Survey of Literature on Controls over International Capital Transactions," IMF Staff Papers, December 1996, 43, 639-87.

Eichengreen, Barry, "One Money for Europe? Lessons from the US Currency Union," Economic Policy, April 1990, 10, 118-87. 
Eichengreen, Barry, Globalizing Capital: A History of the International Monetary

System. Princeton, NJ: Princeton University Press, 1996.

Feldstein, Martin, and Charles Horioka, "Domestic Saving and International Capital Flows," Economic Journal, June 1980, 90, 314-29.

Fischer, Stanley, "Summing Up." In Calvo, Guillermo A., Morris Goldstein, and Eduard Hochreiter, eds., Private Capital Flows to Emerging Markets after the Mexican Crisis.

Washington, D.C.: Institute for International Economics, 1996, pp. 321-25.

Fischer, Stanley, "Capital Account Liberalization and the Role of the IMF." Paper presented at the seminar "Asia and the IMF," Hong Kong, China, September 19, 1997.

Folkerts-Landau, David, et al., International Capital Markets: Developments, Prospects, and Key Policy Issues. Washington, D.C.: International Monetary Fund, November 1997.

Frankel, Jeffrey A., "Quantifying International Capital Mobility in the 1980s." In On Exchange Rates. Cambridge, MA: MIT Press, 1993.

French, Kenneth R., and James M. Poterba, "Investor Diversification and International Equity Markets," American Economic Review, Papers and Proceedings, May 1991, 81, 222-26.

Garber, Peter M., and Subir Lall, "Derivative Products in Exchange Rate Crises." In Glick, Reuven, ed., Managing Capital Flows and Exchange Rates: Perspectives from the Pacific Basin. New York: Cambridge University Press, 1998.

Gardner, Richard N., Sterling-Dollar Diplomacy in Current Perspective. New York: Columbia University Press, 1980. 
Goldstein, Morris, and Guillermo A. Calvo, "What Role for the Official Sector?" In Calvo, Guillermo A., Morris Goldstein, and Eduard Hochreiter, eds., Private Capital Flows to Emerging Markets after the Mexican Crisis. Washington, D.C.: Institute for International Economics, 1996, pp. 233-82.

Golub, Stephen S., "International Capital Mobility: Net versus Gross Stocks and Flows," Journal of International Money and Finance, December 1990, 9, 424-39.

Grilli, Vittorio, and Gian Maria Milesi-Ferretti, "Economic Effects and Structural Determinants of Capital Controls," IMF Staff Papers, September 1995, 42, 517-51.

Horsefield, J. Keith, ed., The International Monetary Fund 1945-1965, vol. 3. Washington, D.C.: International Monetary Fund, 1969.

King, Mervyn, "Tax Systems in the 21st Century," Paper presented at the Fiftieth Congress of the International Fiscal Association, Geneva, September 1996.

Lewis, Karen K., "Investor Home Bias in International Finance and Business Cycles." Unpublished manuscript, Wharton School, University of Pennsylvania, 1997.

Lucas, Robert E., Jr., "Supply-Side Economics: An Analytical Review," Oxford Economic Papers, April 1990, 42, 293-316.

McKinnon, Ronald I., The Order of Economic Liberalization: Financial Control in the Transition to a Market Economy. Baltimore: The Johns Hopkins University Press, 1991.

Marston, Richard C., International Financial Integration: A Study of Interest Differentials between the Major Industrial Countries. Cambridge: Cambridge University Press, 1995. 
Mishkin, Frederic S., "Understanding Financial Crises: A Developing Country

Perspective." In Bruno, Michael, and Boris Pleskovic, eds., Annual World Bank Conference on Development Economics 1996. Washington, D.C.: World Bank, 1996, pp. 29-62.

Mundell, Robert A., "International Trade and Factor Mobility," American Economic

Review, June 1957, 47, 321-35.

Mussa, Michael, and Morris Goldstein, "The Integration of World Capital Markets." In Changing Capital Markets: Implications for Monetary Policy. Kansas City, MO: Federal Reserve Bank of Kansas City, 1993, pp. 245-313.

Obstfeld, Maurice, "Risk-Taking, Global Diversification, and Growth," American Economic Review, December 1994, 85, 1310-29.

Obstfeld, Maurice, "International Capital Mobility in the 1990s," in Kenen, Peter B., ed., Understanding Interdependence: The Macroeconomics of the Open Economy. Princeton, NJ:

Princeton University Press, 1995, pp. 201-61.

Obstfeld, Maurice, "Models of Currency Crises with Self-fulfilling Features," European Economic Review, April 1996, 40, 1037-47.

Obstfeld, Maurice, and Kenneth Rogoff, "The Mirage of Fixed Exchange Rates," Journal of Economic Perspectives, Fall 1995, 9, 73-96.

Obstfeld, Maurice, and Alan M. Taylor, "The Great Depression as a Watershed: International Capital Mobility over the Long Run." In Bordo, Michael D., Claudia D. Goldin, and Eugene N. White, eds., The Defining Moment: The Great Depression and the American Economy in the Twentieth Century. Chicago: University of Chicago Press, 1998, pp. 353-402. 
Officer, Lawrence, H., Between the Dollar-Sterling Gold Points: Exchange Rates, Parity, and Market Behavior. Cambridge: Cambridge University Press, 1996.

Ricardo, David, On the Principles of Political Economy and Taxation. In Sraffa, Piero, ed., The Works and Correspondence of David Ricardo, vol. I. Cambridge: Cambridge University Press, 1951.

Rodrik, Dani, Has Globalization Gone Too Far? Washington, D.C.: Institute for International Economics, 1997.

Siebert, Horst, "Labor Market Rigidities: At the Root of Unemployment in Europe," Journal of Economic Perspectives, Summer 1997, 11, 37-54.

Sørensen, Peter B., "Coordination of Capital Income Taxes in the Economic and Monetary Union: What Needs to be Done?" In Torres, Francisco, and Francesco Giavazzi, eds., Adjustment and Growth in the European Union. Cambridge: Cambridge University Press, 1993, pp. $340-82$.

Tanzi, Vito, "Globalization, Tax Competition and the Future of Tax Systems," IMF Working Paper 96/141, December 1996.

Temin, Peter, Lessons from the Great Depression. Cambridge, MA: MIT Press, 1989. ul Haq, Mahhub, Inge Kaul, and Isabelle Grunberg, eds., The Tobin Tax: Coping with Financial Volatility. New York: Oxford University Press, 1996. 


\section{Endnotes}

1. For discussions of similar data and their interpretation, see Frankel (1993), Mussa and Goldstein (1993), and Obstfeld (1995).

2. If exchange rates are subject to pure speculative shocks unrelated to economic fundamentals and if a government wishes to counter these movements, then its monetary control will be compromised. This possibility motivates James Tobin's proposal for a tax on short-term capital flows--the Tobin tax. As Tobin recognizes, a tax with teeth would have to apply to all foreign exchange transactions, lest it be circumvented by arbitrageurs. Debate on Tobin's proposal continues, but the major industrial countries that maintain floating rates seem to view it as a costly route to highly uncertain gains, particularly in view of the degree of international cooperation that would be needed to plug up loopholes. For analyses of the Tobin tax, including an overview written by Tobin, see the essays collected in ul Haq, Kaul, and Grunberg (1996). Dooley (1996) surveys recent evidence on the recent use of capital controls to attain a variety of objectives. His conclusions, on the whole, are pessimistic.

3. For more detailed discussion see Temin (1989), Eichengreen (1996), Obstfeld and Taylor (1997), and the references therein.

4. Alesina, Grilli, and Milesi-Ferretti (1994) and Grilli and Milesi-Ferretti (1995) report on panel studies of the incidence of capital controls for 20 industrial countries over the years 1950 to 1989 , and for 61 industrial and developing countries over the years 1966 to 1989 . They find that more flexible exchange rate regimes and greater central bank independence lower the probability of capital controls.

5. In a currency-board system, the high-powered money supply is backed entirely by hardcurrency foreign reserves. Some contend that this feature makes currency boards invulnerable to speculative attack, but recent experience bears out the contrary argument in Obstfeld and Rogoff (1995).

6. Collins (1996) studies the determinants of exchange-rate regime choice by developing countries.

7. In an early expression of the concern that capital might flee a nation in favor of lower-tax jurisdictions, David Ricardo argued that the expected future tax burden accompanying a high public debt would induce the rich and their capital to emigrate (Ricardo, 1817 [1951], pp. 247-9). (This is one reason why Ricardo himself rejected the "Ricardian equivalence " of debt and tax finance!)

8. American states also show limited convergence in social benefits. Alan Krueger has pointed out to me that even neighboring states have persistently maintained very different levels of worker protection. 
9. Golub (1990) made a related point, that the gross foreign asset positions of OECD countries -including equities as well as other securities -- are small relative to total domestic financial wealth. But the numbers are greater than for equity alone. In the mid-1990s, U.S. gross foreign assets (of all kinds) were about 10 percent of household net wealth and gross foreign liabilities were about 14 percent.

10. A related phenomenon, first highlighted by Feldstein and Horioka (1980), is the small average size of current account balances for industrial countries over the early postwar period. It is tempting to infer from the Feldstein-Horioka observation that the international capital market indeed has not succeeded in channeling funds out of relatively high-saving countries. However, large foreign imbalances are more evident for smaller countries, and even for bigger countries the Feldstein-Horioka regularity has been attenuated in recent decades.

11. Of course, there are other mechanisms driving such crises, as well. Because domestic interest rates rise, entities that finance long-term domestic lending with short-term domestic borrowing -for example, bank deposits -- come under immediate pressure.

12. Note that baht nominal interest rates will exceed dollar rates when there is some possibility of baht depreciation and the marginal lender of baht does not expect to be fully protected from losses in the event of an exchange-rate change. That configuration is consistent with a higher level of expected government protection on average for capital flows from dollars into baht.

13. An inherent problem facing all countries, industrial and developing alike, is the great difficulty in supervising financial institutions that can deal abroad, beyond the reach of their home supervisors. Since the early 1970s, the Bank for International Settlements has been working to promote international regulatory cooperation and allocate supervisory responsibility for areas that potentially fall under multiple jurisdictions.

14. McKinnon (1991), in particular, has stressed the need for properly sequencing the policy steps leading to an open capital market. 


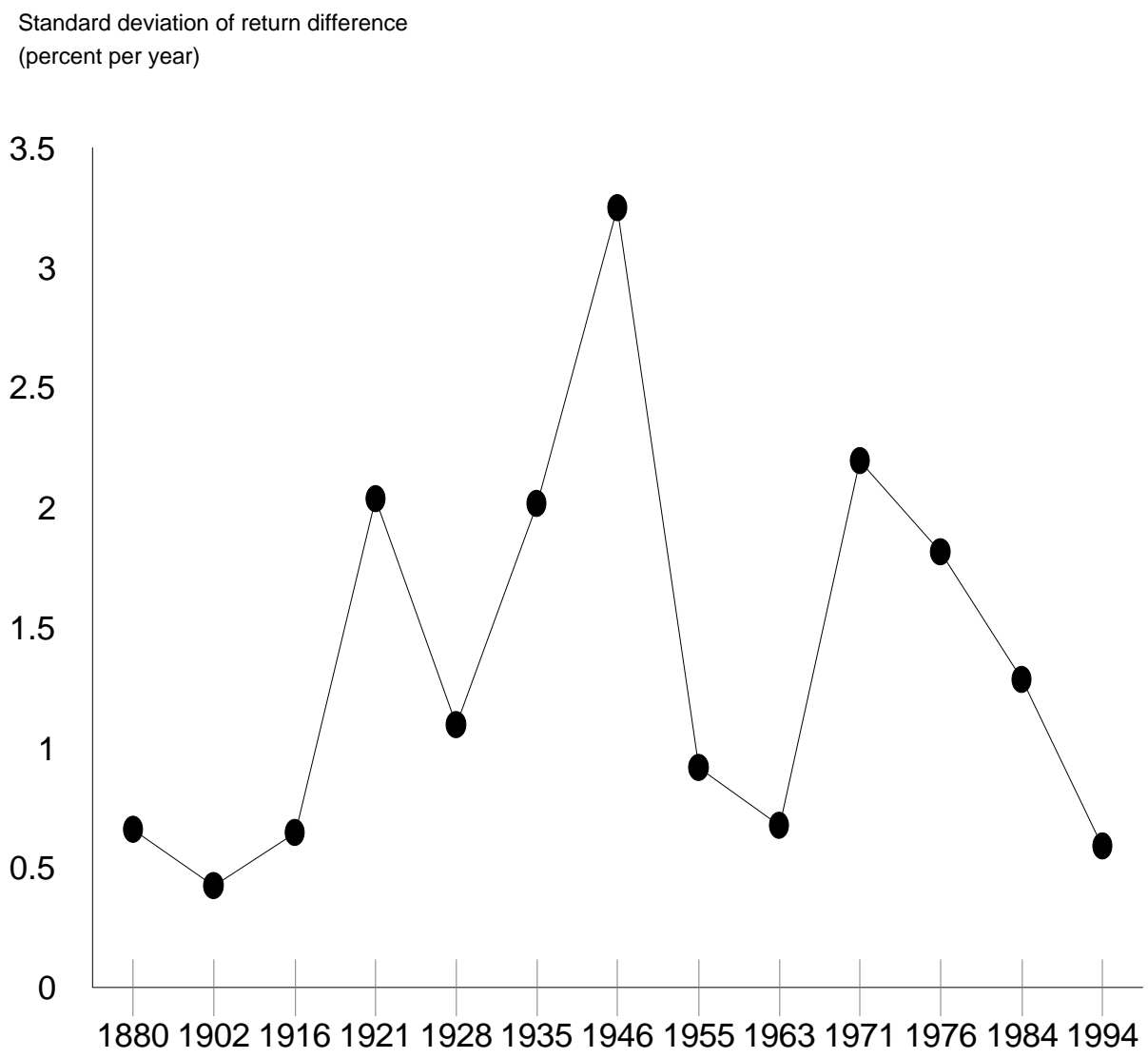


Table 1. Size of Net Capital Flows since 1870 (mean absolute value of current account as percentage of GDP, annual data)

\begin{tabular}{|c|c|c|c|c|c|c|c|c|c|c|c|c|c|}
\hline Period & Argentina & Australia & Canada & Denmark & France & Germany & Italy & Japan & Norway & Sweden & U.K. & U.S. & All \\
\hline $1870-89$ & 18.7 & 8.2 & 7.0 & 1.9 & 2.4 & 1.7 & 1.2 & 0.6 & 1.6 & 3.2 & 4.6 & 0.7 & 3.7 \\
\hline $1890-1913$ & 6.2 & 4.1 & 7.0 & 2.9 & 1.3 & 1.5 & 1.8 & 2.4 & 4.2 & 2.3 & 4.6 & 1.0 & 3.3 \\
\hline 1914-18 & 2.7 & 3.4 & 3.6 & 5.1 & -- & -- & 11.6 & 6.8 & 3.8 & 6.5 & 3.1 & 4.1 & $5.1^{\mathrm{a}}$ \\
\hline 1919-26 & 4.9 & 4.2 & 2.5 & 1.2 & 2.8 & 2.4 & 4.2 & 2.1 & 4.9 & 2.0 & 2.7 & 1.7 & 3.1 \\
\hline $1927-31$ & 3.7 & 5.9 & 2.7 & 0.7 & 1.4 & 2.0 & 1.5 & 0.6 & 2.0 & 1.8 & 1.9 & 0.7 & 2.1 \\
\hline $1932-39$ & 1.6 & 1.7 & 2.6 & 0.8 & 1.0 & 0.6 & 0.7 & 1.0 & 1.1 & 1.5 & 1.1 & 0.4 & 1.2 \\
\hline $1940-46$ & 4.8 & 3.5 & 3.3 & 2.3 & -- & -- & 3.4 & 1.0 & 4.9 & 2.0 & 7.2 & 1.1 & $3.2^{\mathrm{a}}$ \\
\hline $1947-59$ & 3.1 & 3.4 & 2.3 & 1.4 & 1.5 & 2.0 & 1.4 & 1.3 & 3.1 & 1.1 & 1.2 & 0.6 & 1.9 \\
\hline $1960-73$ & 1.0 & 2.3 & 1.2 & 1.9 & 0.6 & 1.0 & 2.1 & 1.0 & 2.4 & 0.7 & 0.8 & 0.5 & 1.3 \\
\hline 1974-89 & 1.9 & 3.6 & 1.7 & 3.2 & 0.8 & 2.1 & 1.3 & 1.8 & 5.2 & 1.5 & 1.5 & 1.4 & 2.2 \\
\hline $1989-96$ & 2.0 & 4.5 & 4.0 & 1.8 & 0.7 & 2.7 & 1.6 & 2.1 & 2.9 & 2.0 & 2.6 & 1.2 & 2.3 \\
\hline
\end{tabular}

Source: Obstfeld and Taylor (1998).

${ }^{a}$ Denotes average with some countries missing. 